\title{
20
}

\section{Land Cover and Land Use Analysis in Coastal Bangladesh}

\author{
Anirban Mukhopadhyay, Duncan D. Hornby, \\ Craig W. Hutton, Attila N. Lázár, \\ Fiifi Amoako Johnson, and Tuhin Ghosh
}

\subsection{Introduction}

In coastal Bangladesh, land use has historically been an indicator of the principal livelihood source for the resident population. The most significant land use intervention has been the development of a system of polders since the 1960s, where areas of land are enclosed by embankments

A. Mukhopadhyay $(\bowtie) \bullet T$. Ghosh

School of Oceanographic Studies, Jadavpur University, Kolkata, India

D. D. Hornby • C. W. Hutton

Geodata Institute, Geography and Environment, University of Southampton, Southampton, UK

\section{A. N. Lázár}

Faculty of Engineering and the Environment and Tyndall Centre for Climate Change Research, University of Southampton, Southampton, UK

F. Amoako Johnson

Social Statistics and Demography, Faculty of Social, Human and Mathematical Sciences, University of Southampton, Southampton, UK 
and water levels are managed using drainage. The widespread development of polders encouraged agriculture but, over the long term, has degraded soil quality by preventing new fertile sedimentation from being deposited and promoting subsidence. Subsidence makes drainage more difficult and increasing potential flood depths when dikes fail (Auerbach et al. 2015). Land use change has also interacted with changes in the balance between sea water and freshwater (Clarke et al. 2015; Lázár et al. 2015) which varies seasonally, inter-annually and spatially in response to changing patterns of precipitation, sea levels, extreme events and water management (Islam et al. 2015).

In order to capture land use changes and provide underlying base for the integrated modelling, two land use maps have been created for the study area (see Chap. 4, Fig. 4.2). The area comprises one of the world's largest lowlands with an elevation up to three metres, one metre above normal high tides, which is subject to tidal exchange. Hence it is the area within Bangladesh most exposed to sea-level rise (Milliman 1991; Huq et al. 1995; World Bank 2010). There are numerous islands near the Meghna River with resident communities. It also includes the Bangladeshi portion of the Sundarbans, the largest mangrove forest in the world.

The first set of land use maps are a historical series from 1989, 2001 and 2010. These compliment the decadal census data and allow for the identification of the change in land use and land cover over a 20-year period, providing a land use trend for the generation of land use scenarios out to 2050. A second set of maps uses the most recent data from 2010; these are composed of the 2010 map used to generate the trend but with additional characteristics derived from secondary data sets available only for this year. The more detailed 2010 map allows detailed identification and analysis of the rise of the aquaculture sector as one major recent land use change.

\subsection{The Development of Land Use Maps}

The land use maps are based on Landsat satellite images. Four scenes were required to cover the whole study area, and scenes with the least cloud cover from January of each selected year were acquired. Four numbers of 
scenes were downloaded to cover the whole study area of each year (1989, 2001 and 2010 of Landsat 5 TM Satellite sensor with a resolution of 30 metres).

To rectify and standardise the classification of the Landsat images for change analysis, radiometric standardisation (Duggin and Robinove 1990; Song et al. 2001) is undertaken along with atmospheric correction to reduce the errors. In this research, Landsat visible and near-infrared (VNIR) bands are atmospherically corrected. The bands are radiometrically calibrated to transform the DN values into top of the atmosphere (TOA) radiance $\left(L_{\mathrm{TOA}}\right)$ using sensor calibration function (Eq. 20.1) (Chander et al. 2007). The radiance of VNIR bands are transformed to correct surface reflectance based on image-based atmospheric correction model developed by Chavez (1996) (Eq. 20.2).

$$
L_{\mathrm{TOA}}=\left(\frac{L_{\max _{\lambda}}-L_{\min _{\lambda}}}{\mathrm{QCAL}_{\text {max }}-\mathrm{QCAL}_{\text {min }}}\right) \times\left(\mathrm{DN}-\mathrm{QCAL}_{\text {min }}\right)+L_{\text {min }_{\lambda}}
$$

Where, $L_{\max _{\lambda}}$ and $L_{\min _{\lambda}}$ are maximum and minimum radiance (in W/ $\left.\mathrm{m}^{-2} \mathrm{sr}^{-1} \mu \mathrm{m}^{-1}\right), \mathrm{QCAL}_{\max }$ and $\mathrm{QCAL}_{\min }$ are maximum and minimum DN value possible (255/1).

$$
\rho=\frac{\left(L_{\mathrm{TOA}}-L_{p}\right) \pi d^{2}}{\operatorname{ESUN}_{\lambda} \cos \theta_{z} T_{z}}
$$

Where

$\rho=$ surface reflectance,

$d=$ Earth sun distance (in Astronomical Units),

$\mathrm{ESUN}_{\lambda}=$ band pass solar irradiance at top of the atmosphere (TOA), $\theta_{z}=$ Solar zenith angle (deg).

$T_{Z}=$ atmospheric transmission between ground and TOA. The values of the $T_{Z}$ for band 4 and 5 were taken as 0.85 and 0.95 respectively (Chavez 1996). 
$L_{p}=$ radiance resulted with the interaction aerosol and atmospheric particles and estimated based on Song et al. (2001), Chavez (1996) and Sobrino et al. (2004). All related atmospheric correction was completed using ATCORE Module of ERDAS imagine software.

\subsection{Image Classification for Historical Maps}

Nine major land use types were considered in this study as they are the predominant land cover classes of the study area: (i) agriculture, (ii) vegetation with rural settlement, (iii) wetland/bare land, (iv) aquaculture, (v) water, (vi) mudflat, (vii) mangrove, (viii) sand and (ix) urban settlement. In order to assess the change in land classes, the Landsat imageries of 1989, 2001 and 2010 were initially analysed using an unsupervised classification which generated 100 classes. This was followed by a supervised classification using maximum likelihood classifier (MLC), one of the most recognised parametric classifiers (Lázár et al. 2015; Melesse and Jordan 2002; Otukei and Blaschke 2010), using training data gathered from the field using handheld GPS. The first five bands of Landsat TM were used in the classification. The algorithm calculates the likelihood of belonging to one of the known classes. The benefit of this method is that it takes into account the variance-covariance matrix within the class distributions (Scott and Symons 1971). It is extensively used where a pixel with the determined likelihood is classified into the consistent class. This classification process was carried out for the three years of data (Fig. 20.1), allowing for the identification of land use change over time, along with trends and rates.

Analysis of the prepared land use land cover maps (Fig. 20.2 and Table 20.1) showed vegetation with rural settlement, aquaculture and urban settlement have been increasing steadily whereas agricultural land shows a large decrease, particularly in the north-west side of the study area where it appears to have been displaced by growing areas of aquaculture. Mangrove areas show a small but steady decreasing trend over the 20-year period. 

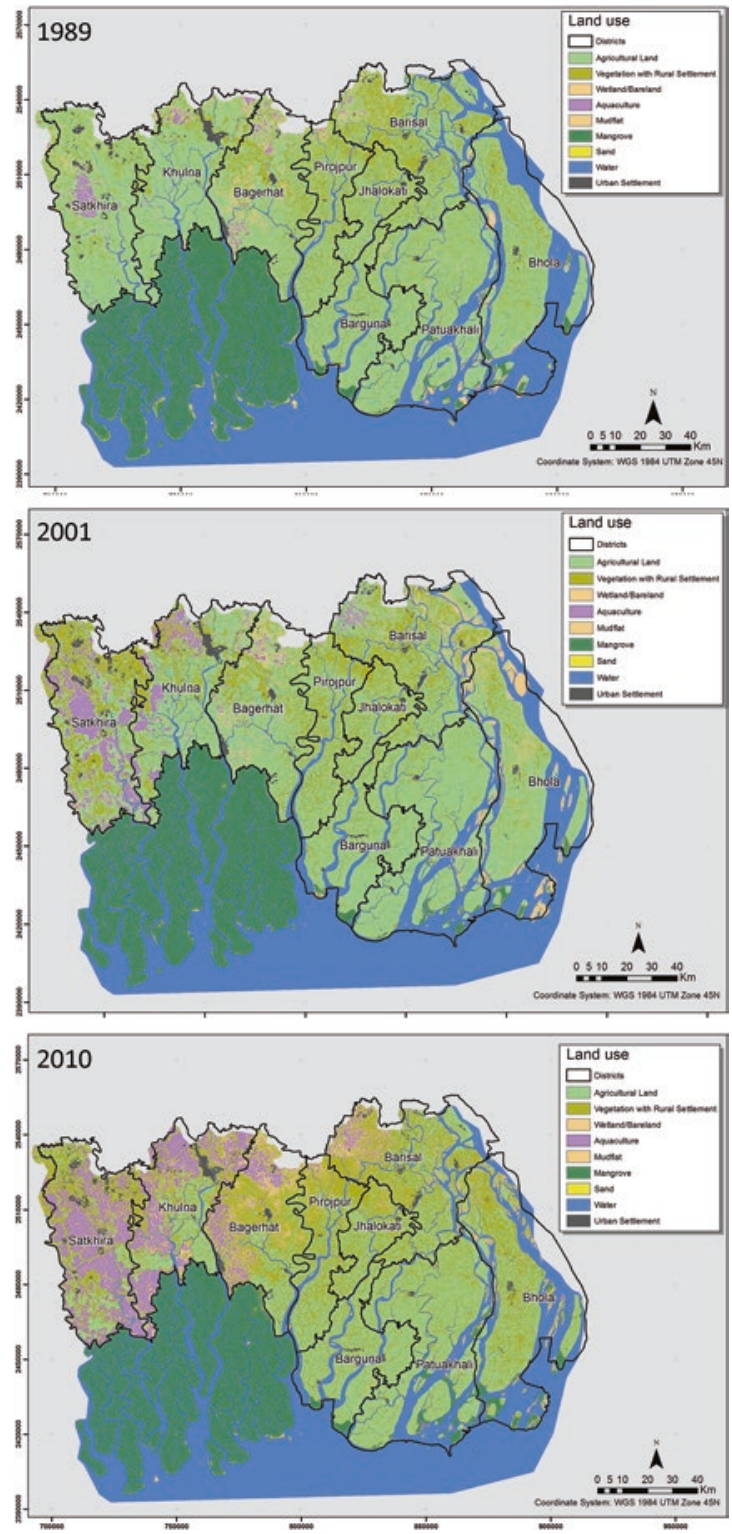

Fig. 20.1 Land use land cover maps for 1989, 2001 and 2010 illustrating changes in the seven predominant land use land cover classes 


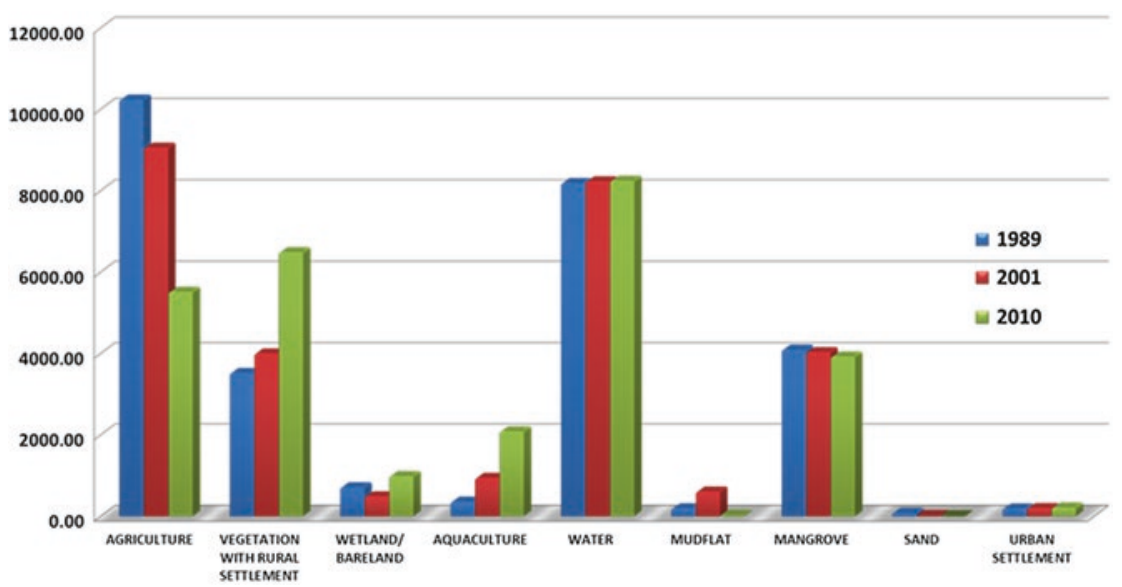

Fig. 20.2 Change in area $\left(\mathrm{km}^{2}\right)$ for the land use land cover classes in the study area

Table 20.1 Table showing the changing trend of the land cover classes of the study area from 1989 to 2010

\begin{tabular}{lccc}
\hline Class & 1989 area $\left(\mathrm{km}^{2}\right)$ & 2001 area $\left(\mathrm{km}^{2}\right)$ & 2010 area $\left(\mathrm{km}^{2}\right)$ \\
\hline Agriculture & 10,240 & 9,059 & 5,517 \\
Vegetation with & 3,524 & 4,003 & 6,490 \\
$\quad$ rural settlement & & & \\
Wetland/bareland & 717 & 494 & 989 \\
Aquaculture & 362 & 947 & 2090 \\
Water & 8,190 & 8,233 & 8,247 \\
Mudflat & 198 & 610 & 21 \\
Mangrove & 4,098 & 4,037 & 3,925 \\
Sand & 81 & 12 & 3 \\
Urban settlement & 196 & 207 & 215 \\
\hline
\end{tabular}

\subsection{Extraction of Aquaculture and Trend Analysis}

Aquaculture in the Ganges-Brahmaputra-Meghna delta significantly impacts on livelihoods, employment and land tenure (Belton et al. 2011; Little et al. 2012; Kamruzzaman 2014) and is an important and growing 
land use within the study area. Since the infrared band is mostly absorbed by water, areas featuring water will be darker than surrounding areas in the satellite images. Indices used in this study for classifying water bodies were the Normalised Difference Water Index (NDWI) and Modified Normalised Difference Water Index (MNDWI) (Acharya et al. 2016). In both the water indices used, water pixels have a positive value, but differentiation between aquacultural and non-aquacultural ponds is unclear. An object-oriented image classification was therefore utilised within the study to take advantage of the fact that aquaculture ponds tend to have a specific shape and size.

Figure 20.3 indicates the spatial distribution of aquaculture and its persistence between 1989 and 2010 as calculated by the number of years identified (maximum of seven). For example, the orange colour denotes that this land has been classified as aquaculture five of the seven times. This type of analysis shows the progressive growth of aquaculture notwithstanding small areas where land has alternated in use. The growth of the shrimp industry over the last 20 years (Fig. 20.4) would appear to be associated, at least initially, with the development of the main road systems radiating out from the Khulna city south-west.

Aquaculture is replacing rice fields throughout the region that can no longer produce sufficiently in the increased saline environment. The exchange of shrimp for rice has socio-economic impacts with reductions in the localised population density, as rice farming is lost as well as the potential reduction in employment associated with the more intensive farming methodologies being associated with migration.

\subsection{Differentiating Saline and Freshwater Aquaculture}

Differentiating between saline and freshwater aquaculture is an important aspect of the Landsat analysis. A new method is applied to the most recent Landsat 5 TM images from January 2010 which involves field verification. The Landsat scenes are initially processed using ENVI 5.0 (Exelis Visual Information Solutions, USA). They are passed through the 


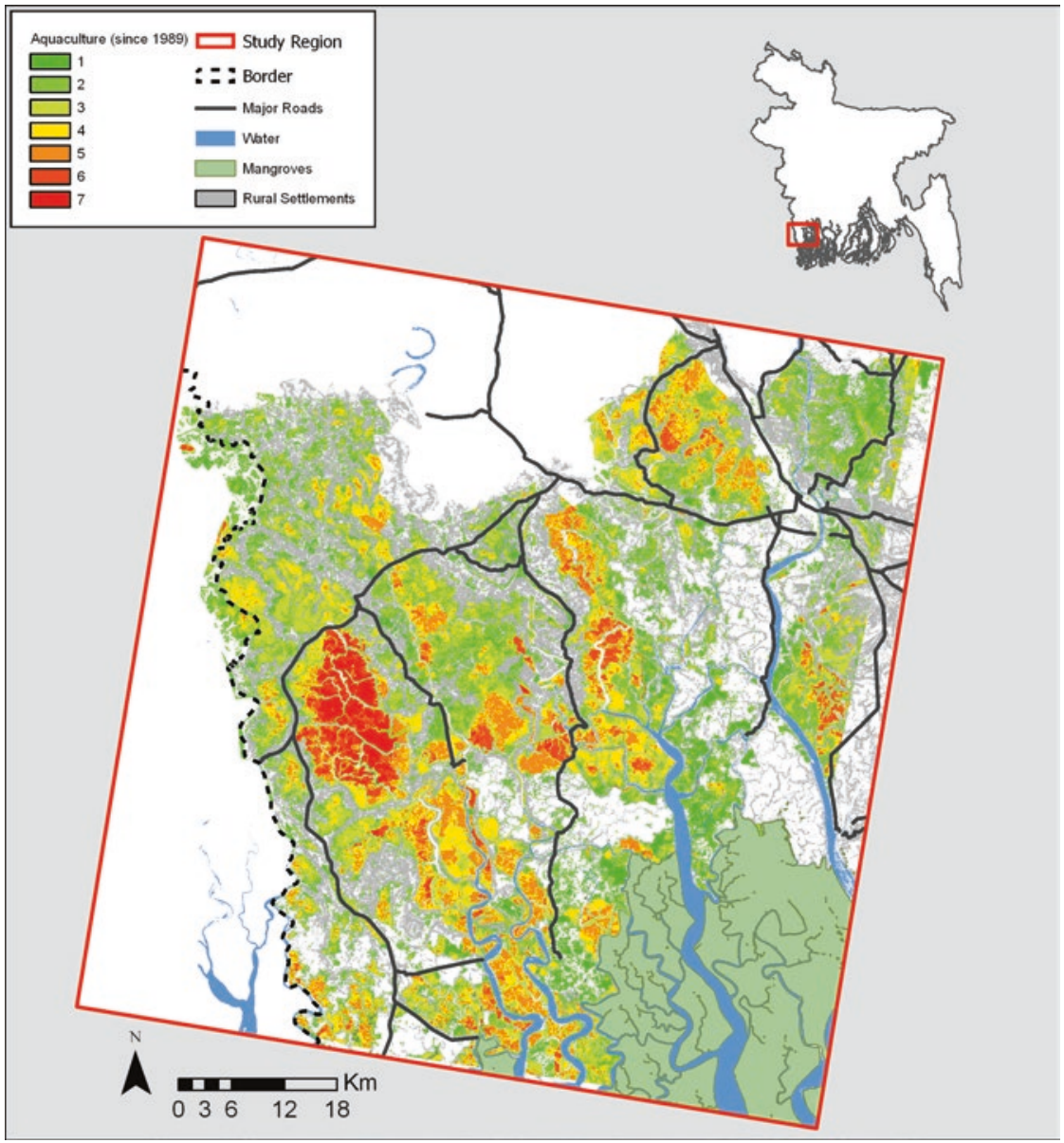

Fig. 20.3 Persistence of aquacultural land use over the period 1989-2010 in the north-west of the study area

radiometric calibration tool and then atmospherically corrected using the FLAASH tool with all downstream processing carried out in ArcGIS 10.2. Three Landsat bands (4, 5 and 3) are combined to make a composite image. This combination shows up water as a deep purple and vegetation as shades of brown and orange colours. This composite is the base layer for all subsequent processing. The 4-5-3 composite image is then 


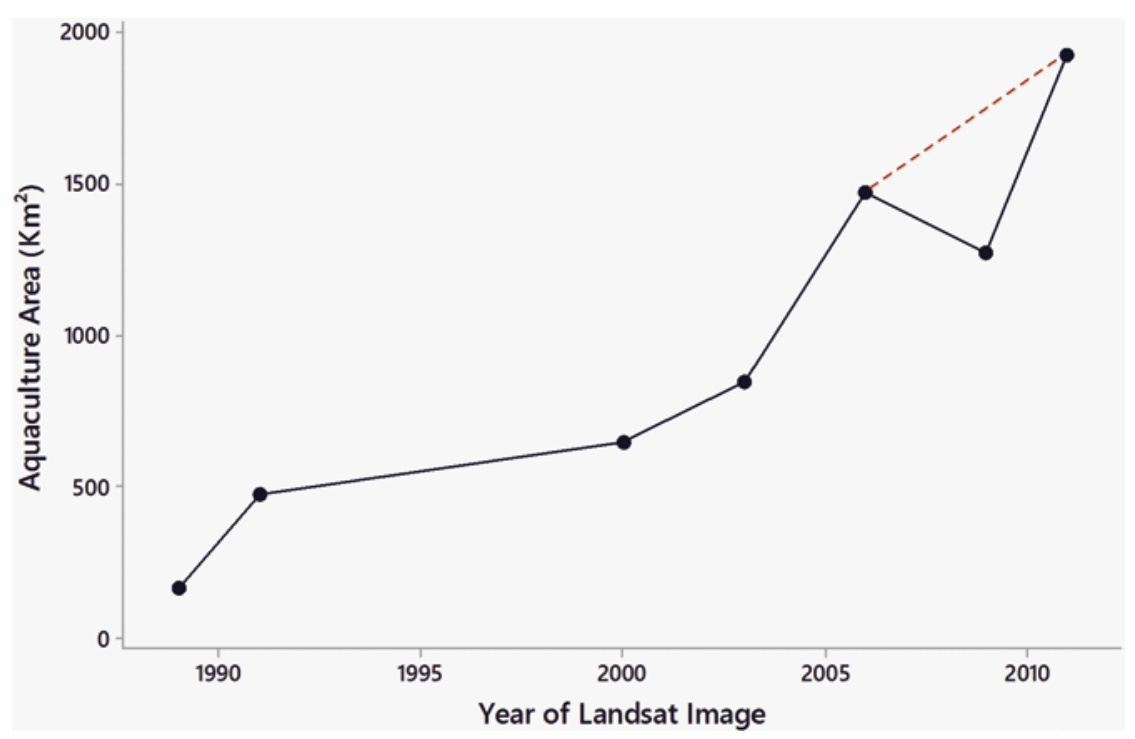

Fig. 20.4 Area under aquaculture in the study area derived from Landsat data. The reduction in area suggested by the 2009 data point is potentially due to cloud cover in the imagery

run through an isocluster tool which is an unsupervised classification technique and is set to create ten initial classes. The grid is then clipped back to the area of interest by the Union dataset to reduce the amount of data that needed processing, and a majority filter was run on the clipped image to subsume individual pixels.

The base layer is then modified to account for inaccuracies. A separate raster using the NDWI equation (McFeeters 1996) is created from the ENVI output and river pixels are extracted. As this would include flooded land, this dataset is vectorised and a manual pass of identifying rivers done. The aim of this is to distinguish between what are clearly rivers and temporarily flooded fields. The identified rivers are then rasterised and mosaicked or "stamped" back onto the majority-filtered grid. The perimeter of the urban areas Khulna and Barisal are also digitised and stamped back onto the grid. Areas of irrigated agriculture were distinguished from mangrove areas using a manually digitised mask to reclassify pixels that 
are erroneously classified by the isocluster tool into the mangrove class. A separate dataset that distinguished between irrigated and non-irrigated agriculture is also utilised. The newly identified irrigated agriculture polygons are also rasterised and stamped back onto the grid. These cells corresponded well to what was being classified as simply agriculture by the isocluster tool.

A further modification of the base layer uses a land use dataset for 2014 created by CEGIS in Bangladesh which differentiates between saline and freshwater aquaculture. This is supported by stakeholder evidence (see Chap. 10) and reference to available literature. The resultant map, Fig. 20.5, provides the basis for other research as well as the integrated model (e.g. Chaps. 21, 22 and 28).

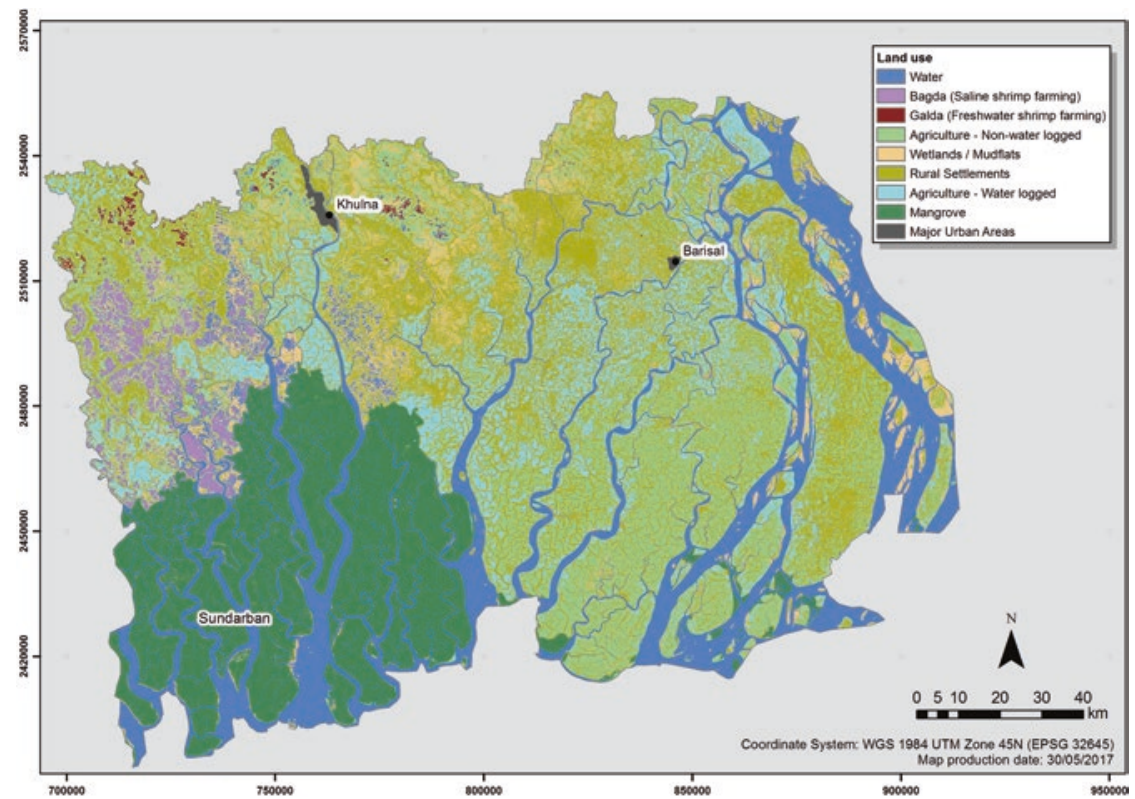

Fig. 20.5 Classification of 2010 Landsat Imagery of the study area into nine land use classes using remote sensing supported by ground truth data relating to the saline shrimp farming in the west of the study area (Reprinted under Creative Commons Attribution 4.0 International License from Amoako Johnson et al. 2016) 


\subsection{Scenarios of Future Land Use}

Rather than simply extrapolating historical trends, future land use scenarios were developed for the study area based on stakeholder's scenario narratives for 2050 under the business as usual (BAU) scenario (e.g. brackish shrimp area slightly increased due to conversion of natural vegetation). The narratives are quantified through a process of qualitative to quantitative translation by experts and, after a final stakeholder workshop, the quantifications were projected to 2050 using agreed per cent changes from the 2011 land use baseline. The analysis does not extend beyond 2050, not least due to the large uncertainties in social and political trends more than 40 years into the future.

The land use scenarios were therefore linked to the expert demographic and socio-economic scenarios. Land use scenarios utilised in this context are a novel way to unify socio-economic and biophysical scenarios with changes in land use and land cover acting as a main driver of the scenario modelling process. Whilst such an approach allowed for land use to act as a central driver for modelling the relationship between people and ecosystem services, it also critically allows stakeholders to envisage a future in terms with which they are familiar, land use being an aspect of the dayto-day lives of the local population and decision makers.

\subsection{Discussion}

The land use base map and scenarios outlined here are fundamental to integrated analysis of ecosystems, environmental change and social sustainability in the delta. The land use information, for example, can be used to establish the role of tenure, or exposure to environmental stress, as a constraint on livelihoods and the spatial distribution of poverty (see Chap. 21). The maps developed show a picture of rapid change over the past two or three decades in the delta, notably the consolidation of polders and agriculture within them, and a significant increase in the prevalence of brackish shrimp farming with aquaculture mainly replacing rice fields. This is a process that might reasonably be set to continue into the 
future and almost certainly within the context of the development of the Bangladesh Delta Plan 2100 (BDP2100 2015), which will see substantial coastal infrastructural development raising the value of land and formalising agricultural structures. This is likely to include the further development of current polders and possibly see the introduction of further water and sediment management processes.

The trend of conversion for aquaculture has occurred concurrently with an increase in salinity which itself has been associated with a rise in poverty across the study region (Amoako Johnson et al. 2016). Indeed this region has shown a substantial growth in shrimp farming in the last 20 years as shown in the land use maps. This process is often associated with the presence of salinity and is thus highly likely to continue with future levels of salinity (see Chaps. 17 and 18). The growth of the shrimp-based aquaculture appears to be associated with both the intrusion of salt but also the proximity of a substantial settlement, in this case of Khulna, where rapid processing of the perishable product can be undertaken. This association is supported by access to main road systems which can be seen to be associated with the main hotspots of shrimp industry development.

At one level this growth might be viewed as a useful adaptation to increasing salinity intrusion in the region (Belton et al. 2011; Primavera 1997; Paul and Vogl 2011; Kamruzzaman 2014). Indeed, the high demand and perceived monetary benefits of shrimp has inspired many farmers to convert farmlands intruded by saline water into shrimp farms, whilst others have actively encouraged saline water from marine sources into their farmlands to produce shrimp (Rahman et al. 2013). However, the environmental impacts of this intense aquaculture practice (e.g. increasing soil toxicity) raise concerns over its sustainability. Intensive aquaculture, as identified in the mapping, has consequences for land tenure, livelihood displacements and income loss, food insecurity and health, rural unemployment, social unrest, conflicts and forced migration (Hossain et al. 2013; Swapan and Gavin 2011; Paul and Vogl 2011). As such the monitoring of shrimp farming by remote sensing offers a valuable insight into changes in socio-environmental context linked via land use change and offers future scenarios the trend in growth of brackish shrimp farming. 


\section{References}

Acharya, T.D., D.H. Lee, I.T. Yang, and J.K. Lee. 2016. Identification of water bodies in a Landsat 8 OLI image using a J48 decision tree. Sensors 16 (7). https://doi.org/10.3390/s16071075.

Amoako Johnson, F., C.W. Hutton, D. Hornby, A.N. Lázár, and A. Mukhopadhyay. 2016. Is shrimp farming a successful adaptation to salinity intrusion? A geospatial associative analysis of poverty in the populous Ganges-Brahmaputra-Meghna Delta of Bangladesh. Sustainability Science 11 (3): 423-439. https://doi.org/10.1007/s11625-016-0356-6.

Auerbach, L.W., S.L. Goodbred, D.R. Mondal, C.A. Wilson, K.R. Ahmed, K. Roy, M.S. Steckler, C. Small, J.M. Gilligan, and B.A. Ackerly. 2015. Flood risk of natural and embanked landscapes on the Ganges-Brahmaputra tidal delta plain. Nature Climate Change 5 (2): 153-157. https://doi.org/10.1038/ nclimate2472.

BDP2100. 2015. Coast and polder issues: Baseline study. Bangladesh Delta Plan. General Economic Division, Planning Commission, Government of the People's Republic of Bangladesh. http://www.bangladeshdeltaplan2100.org/ publications/baseline-studies/. Accessed 19 July 2016.

Belton, B., M. Karim, S. Thilsted, K. Murshed-E-Jahan, W. Collis, and M. Phillips. 2011. Review of aquaculture and fish consumption in Bangladesh. Studies and reviews 2011-53. Penang: The WorldFish Center. http://pubs. iclarm.net/resource_centre/WF_2970.pdf. Accessed 8 Dec 2016.

Chander, G., B.L. Markham, and J.A. Barsi. 2007. Revised Landsat-5 thematic mapper radiometric calibration. IEEE Geoscience and Remote Sensing Letters 4 (3): 490-494. https://doi.org/10.1109/LGRS.2007.898285.

Chavez, P.S. 1996. Image-based atmospheric corrections revisited and improved. Photogrammetric Engineering and Remote Sensing 62 (9): 1025-1036.

Clarke, D., S. Williams, M. Jahiruddin, K. Parks, and M. Salehin. 2015. Projections of on-farm salinity in coastal Bangladesh. Environmental Science-Processes and Impacts 17 (6): 1127-1136. https://doi.org/10.1039/ c4em00682h.

Duggin, M.J., and C.J. Robinove. 1990. Assumptions implicit in remotesensing data acquisition and analysis. International Journal of Remote Sensing 11 (10): 1669-1694.

Hossain, M.S., M.J. Uddin, and A.N.M. Fakhruddin. 2013. Impacts of shrimp farming on the coastal environment of Bangladesh and approach for management. Reviews in Environmental Science and Bio-Technology 12 (3): 313-332. https://doi.org/10.1007/s11157-013-9311-5. 
Huq, S., S.I. Ali, and A.A. Rahman. 1995. Sea-level rise and Bangladesh: A preliminary analysis. Journal of Coastal Research SI 14: 44-53.

Islam, G.M.T., A. Islam, A.A. Shopan, M.M. Rahman, A.N. Lázár, and A. Mukhopadhyay. 2015. Implications of agricultural land use change to ecosystem services in the Ganges delta. Journal of Environmental Management 161: 443-452. https://doi.org/10.1016/j.jenvman.2014.11.018.

Kamruzzaman, P. 2014. Poverty reduction strategy in Bangladesh: Rethinking participation in policy making. Bristol: Policy Press.

Lázár, A.N., D. Clarke, H. Adams, A.R. Akanda, S. Szabo, R.J. Nicholls, Z. Matthews, D. Begum, A.F.M. Saleh, M.A. Abedin, A. Payo, P.K. Streatfield, C. Hutton, M.S. Mondal, and A.Z.M. Moslehuddin. 2015. Agricultural livelihoods in coastal Bangladesh under climate and environmental change A model framework. Environmental Science-Processes and Impacts 17 (6): 1018-1031. https://doi.org/10.1039/c4em00600c.

Little, D.C., B.K. Barman, B. Belton, M.C. Beveridge, S.J. Bush, L. Dabaddle, H. Demaine, P. Edwards, M.M. Haque, G. Kibria, E. Morales, F.J. Murray, W.A. Leschen, M.C. Nandeesha, and F. Sukadi. 2012. Alleviating poverty through aquaculture: progress, opportunities and improvements. In Farming the waters for people and food: Proceedings of the Global Conference on Aquaculture 2010, Phuket. September 22-25, 2010, ed. R.R. Subasinghe, J.R. Arthur, D.M. Bartley, S.S. De Silva, M. Halwart, N. Hishamunda, C.V. Mohan, and P. Sorgeloos, 719-783. Rome/Bangkok: FAO and NACA. McFeeters, S.K. 1996. The use of the normalized difference water index (NDWI) in the delineation of open water features. International Journal of Remote Sensing 17 (7): 1425-1432.

Melesse, A.M., and J.D. Jordan. 2002. A comparison of fuzzy vs. augmentedISODATA classification algorithms for cloud-shadow discrimination from Landsat images. American Society for Photogrammetry and Remote Sensing 68 (9): 905-912.

Milliman, J.D. 1991. Flux and fate of fluvial sediment and water in coastal seas. In Ocean margin processes in global change: report of the Dahlem Workshop on Ocean Margin Processes in Global Change, Berlin. March 18-23, 1990, ed. R.F.C. Mantoura, J.M. Martin, and R. Wollast, 69-89. Chichester: Wiley.

Otukei, J.R., and T. Blaschke. 2010. Land cover change assessment using decision trees, support vector machines and maximum likelihood classification algorithms. International Journal of Applied Earth Observation and Geoinformation 12: S27-S31. https://doi.org/10.1016/j.jag.2009.11.002.

Paul, B.G., and C.R. Vogl. 2011. Impacts of shrimp farming in Bangladesh: Challenges and alternatives. Ocean and Coastal Management 54 (3): 201-211. https://doi.org/10.1016/j.ocecoaman.2010.12.001. 
Primavera, J.H. 1997. Socio-economic impacts of shrimp culture. Aquaculture Research 28 (10): 815-827.

Rahman, M.M., V.R. Giedraitis, L.S. Lieberman, T. Akhtar, and V. Taminskiene. 2013. Shrimp cultivation with water salinity in Bangladesh: The implications of an ecological model. Universal Journal of Public Health 1 (3): 131-142. http://dx.doi.org/10.13189/ujph.2013.010313.

Scott, A.J., and M.J. Symons. 1971. Clustering methods based in likelihood ration criteria. Biometrics 27 (2): 387. https://doi.org/10.2307/2529003.

Sobrino, J.A., J.C. Jimenez-Munoz, and L. Paolini. 2004. Land surface temperature retrieval from LANDSAT TM 5. Remote Sensing of Environment 90 (4): 434-440. https://doi.org/10.1016/j.rse.2004.02.003.

Song, C., C.E. Woodcock, K.C. Seto, M.P. Lenney, and S.A. Macomber. 2001. Classification and change detection using Landsat TM data: When and how to correct atmospheric effects? Remote Sensing of Environment 75 (2): 230-244. https://doi.org/10.1016/S0034-4257(00)00169-3.

Swapan, M.S.H., and M. Gavin. 2011. A desert in the delta: Participatory assessment of changing livelihoods induced by commercial shrimp farming in Southwest Bangladesh. Ocean and Coastal Management 54 (1): 45-54. https://doi.org/10.1016/j.ocecoaman.2010.10.011.

World Bank. 2010. Economics of adaptation to climate change: Bangladesh. Vol. 1 main report. Washington, DC: World Bank Group. https://openknowledge. worldbank.org/handle/10986/12837. Accessed 9 Jan 2017.

Open Access This chapter is licensed under the terms of the Creative Commons Attribution 4.0 International License (http://creativecommons.org/ licenses/by/4.0/), which permits use, sharing, adaptation, distribution and reproduction in any medium or format, as long as you give appropriate credit to the original author(s) and the source, provide a link to the Creative Commons license and indicate if changes were made.

The images or other third party material in this chapter are included in the chapter's Creative Commons license, unless indicated otherwise in a credit line to the material. If material is not included in the chapter's Creative Commons license and your intended use is not permitted by statutory regulation or exceeds the permitted use, you will need to obtain permission directly from the copyright holder.

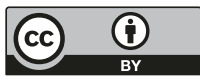

